\title{
Does CSR Enhance Young Bank Customers' Satisfaction and Loyalty in a Developing Economy? The Mediating Role of Trust
}

\author{
Stella Zulu-Chisanga
}

Copperbelt University, Zambia: stellachi77@gmail.com

\begin{tabular}{l} 
ARTICLE DETAILS \\
\hline History \\
Revised format: November 2019 \\
Available Online: December 2019
\end{tabular}

Keywords

Corporate Social Responsibility,

Trust, Customer Satisfaction and Loyalty

\section{JEL Classification:}

M14,L16,L19

\begin{abstract}
The role of corporate social responsibility (CSR) on firm performance is well documented in the literature. Although the majority of the evidence available points to a positive association between CSR and determinants of company performance such as monetary performance, personnel commitment and corporate identity, findings still remain rather inconclusive as negative or no correlation results are also reported. In addition, little is known about how CSR is perceived from a bank customer's point of view and studies examining its effect on customer satisfaction and loyalty in developing economies are scanty. Drawing insights from the stakeholder and signaling theories, this study examines the effect of CSR on customer satisfaction and customer loyalty. The study also examines the mediating role of trust on these relationships. Data from 348 bank customers in Zambia indicates that CSR positively affects satisfaction and loyalty. It was also established that trust has a significant mediating effect on the relationships. With the increase in complexity and dynamism of today's business environment banks are advised to be more socially responsible as one way of building trust and customer satisfaction and loyalty.
\end{abstract}

(C) 2019 The authors, under a Creative Commons Attribution-Non Commercial 4.0

Corresponding author's email address: stellachi77@gmail.com

Recommended citation: Chisanga, S. Z., (2019). Does CSR Enhance Young Bank Customers' Satisfaction and Loyalty in a Developing Economy? The Mediating Role of Trust. Journal of Accounting and Finance in Emerging Economies, 5 (2), 325-342

DOI: $10.26710 /$ jafee.v5i2.938

\section{Introduction}

Corporate Social Responsibility (CSR), defined as the obligation of businesses to take actions that protect and improve the welfare of all stakeholders (Friedman, 1970; Davis, 1975), has over the past years attracted much attention from academicians and business managers. Researchers suggest that CSR is an effective strategic tool to create a long-term competitive edge for a firm and has a positive impact on performance (McGuire et al., 1988; Graves and Waddock, 1994; Schwartz and Carroll, 2003; Khan et al., 2013; Carroll, 2016). The understanding is that a firm with policies and practices that protect and contribute to the wellbeing of its various stakeholders such as society, customers, employees, rather than business owners only, is more likely to build a strong reputation and reap a variety of benefits such as 
attracting qualified and committed employees, positively influencing buyer behavior and gaining favour from government authorities (Collier and Esteban, 2007; Kim, et al., 2010; Martínez and Rodríguez, 2013). However, other researchers argue that CSR is a costly activity that could harm performance (e.g., Bromiley and Marcus, 1989; Wright and Ferris, 1997; Story and Neves, 2015; Wu and Shen, 2013), and still others claim that CSR does not significantly relate to performance (e.g., Aupperle et al., 1985; Teoh et al., 1999; McWilliams and Siegel, 2001; Paulik et al., 2015). Although relatively more studies have found a positive relationship between CSR and firm performance, results still remain inconclusive (Story and Neves, 2015).

An additional important deficiency in the literature is how CSR is perceived from a customer's point of view (Kiessling et al., 2016). Indeed, while CSR scholars have called for more CSR research to be directed toward how a company's CSR activities affect customer bahaviours (Kiessling etal., 2016; Bondy et al., 2012; Harrison et al., 2010; Ziek, 2009), little is known on how CSR affects customers in many developing African countries. More specifically, a review of the literature indicates that the few studies on CSR in Zambia, a developing African country and the setting of this study, have largely focused on the mining sector (Lungu and Shikwe, 2006; Choongo, 2017), to the neglect of not only CSR practices in other sectors such as banking but also other performance outcomes like customer satisfaction and loyalty. To highlight, the role of CSR on customer satisfaction and customer loyalty in the banking sector in most developing economies is not clear in the literature. Besides, although scholars have investigated the relationship between CSR and customer loyalty in developed economies (e.g., Martínez and del Bosque, 2013; Chung, et al., 2015), very few studies examine the role that trust plays as a mediator of the relationship. Yet trust is a fundamental ingredient in building relationships between customers and service providers and has significant implications when it comes to marketing outcomes such as customer satisfaction and loyalty (Yadav et al., 2018).

Accordingly, the aim of this study is to empirically examine the effect of CSR on bank customer satisfaction and customer loyalty both directly and indirectly through trust in a developing-economy. The study draws insights from the stakeholder and signaling theories to posit that CSR has both direct and indirect through trust, effects on customer satisfaction and customer loyalty. Our contention is that a firm's CSR engagement is a basis for consumers to evaluate a company's products and services. As such, we see CSR as one of the effective ways to retain customers and possibly attract new ones for banks at a time of rising international competition, increased customer expectations, oversupplied and mature markets and lower switching costs (Saeidi et al., 2015). We argue, first, that a firm's CSR activities customers perceive to be positive can lead to high customer satisfaction and customer loyalty. Second, we contend that a firm with more CSR activities is able to signal a positive image and build customer trust and in turn increase customer satisfaction and customer loyalty. Both the stakeholder and signalling theories, which suggest that greater CSR activities help firms create social legitimacy among its various stakeholders and boost a firm's reputation assets (Fombrum et al., 2000), support our contention.

By so doing, this study enriches scholarly knowledge explicitly showing how CSR activities of banks in a developing economy help build customer satisfaction and customer loyalty. The fact that prior research has focused mainly on understanding CSR and customer loyalty in firms located in developed-economy markets, means that there is little understanding in the literature of potential variations in CSR outcomes in firms located in developing African markets. Yet, as George et al. (2016) posit, developing African countries such as Zambia present an exciting context and rare opportunity to advance knowledge to existing business theories and to test their relevance beyond the developed economy context. Indeed, since social-economic factors and institutional arrangements in developed countries may be different to those of developing economies, there is ground for research in developing economies (Hoskisson et al., 2000; Visser, 2006; Xu and Meyer, 2013). By testing the conceptual model on Zambian-based banks, the study provides evidence of the applicability of not only the CSR phenomenon but also Western developed 
and validated measures beyond the developed economy context and is a timely response to appeals to business strategy researchers to embrace developments in such regional settings to advance the development of theory and practice (George et al., 2016; Jamali and Karam, 2018). Further, the study empirically examines the under-researched mediating role of trust on the relationship between CSR and customer satisfaction and loyalty. Bank managers and policy makers are encouraged to invest more in CSR activities to build customer trust, a relevant ingredient for customer satisfaction and loyalty.

In the section that follows next, we present a review of the literature and theoretical framework as well as the study's hypotheses. We then explain the methods we used to test our model and later present findings of the study. A discussion of the results in terms of implications to theory and practice is given. The study concludes by suggesting directions for further research.

\section{Literature Review, Theoretical Framework and Hypotheses Development}

There is consensus in the literature that a firm has a responsibility to not only produce and market goods and services that meet people's needs and make profit but also cooperate with society to solve problems which might have been caused by the side effects of the business activities (Maignan and Ferrell, 2004; Carroll and Shabana, 2010; Mishra and Modi, 2016; Grayson and Hodges, 2017). Accordingly, CSR is a commitment to enhance societal well-being using discretionary business practices as well as contributions of corporate resources (Kotler and Lee, 2005;2008) and is believed to be an irrefutable priority, an opportunity as well as a competitive advantage for most firms around the world (Lam and Lim, 2016). Scholars submit that CSR should be a conscious and consistent commitment to fully comply with the purpose of the company both internally and externally, considering the expectations of all participants which may be economic, social or human and environmental, as well as demonstrating respect for ethical values, people, communities and the environment to build the common good (Aguilera et al., 2007; Murray and Vogel, 1997; Sourvinou and Filimonau, 2018). By so doing, firms gain advantages that are reflected in qualitative and quantitative benefits.

CSR activities can range from pure philanthropic community engagements such as charitable contributions to more strategic activities that enhance firm performance such as employee commitment, increased attractiveness or reputation of the firm to its stakeholders and positive consumer orientation and purchase behaviour (Carroll, 1999; Owen and Scherer, 1993; Cone et al., 2003; Stanwick and Stanwick, 1998; Perez-Batres et al., 2012). For example, studies by Kim et al. (2010), Korschun et al. (2014) and Lee et al. (2013) provide evidence that socially responsible companies record higher performance due to increased employee commitment and productivity. Also, several marketing studies suggest that CSR can positively affect consumers' attitudes towards the firm and its products and services (e.g., Vlachos et al., 2009; Kotler and Lee, 2005; Ailawadi et al., 2014; Chung et al., 2015; He and Li, 2011; Marin et al., 2009; Brown and Dacin, 1997; Lichtenstein et al., 2004). There is evidence that a companies' CSR activities such as participation in humanitarian events, cause-related marketing and sponsorship of local events are more likely to influence consumer behavior such as word of mouth advocacy, purchase, and the creation of higher customer loyalty (Alafi and Hasoneh, 2012; Chung et al., 2015).

Within the banking sector, CSR is rapidly gaining importance world over (McDonald and Rundle-Thiele, 2008; Poolthong and Mandhachitara, 2009; Hoang, 2014; Paulik et al., 2015; Alafi and Al sufy, 2012) and is viewed as one way of differentiating one brand from the other and enhancing performance. For example, Mocan et al's (2015) study indicates that CSR is a relevant strategic tool in the banking industry that improves economic efficiency, enhances company reputation, employee loyalty and communication between the banking industry and society. Shen et al. (2016) also provide evidence that CSR oriented banks outperform non-CSR banks in terms of return on assets and return on equity. Branco and Rodrigues (2008) also reveal that social responsibility disclosure (SRD) on the internet by Portuguese banks is part of the strategies banks use to enhance reputation. Although these studies show that CSR can bring many 
advantages for the banking sector, Paulik et al. (2015) study however shows that customers' perception of CSR does not have significant effect on their satisfaction. Also, a more comprehensive study of 162 banks in 22 countries by $\mathrm{Wu}$ and Shen (2013) indicates that while CSR is both positively associated with financial performance in terms of return on assets, return on equity, net interest income, and non-interest income, CSR is negatively associated with non-performing loans.

In Zambia, a developing Sub-Saharan African economy, most banks have become more interested in and have embraced CSR in an effort to differentiate themselves and influence positive customer perception to achieve sustainable competitive advantage (Zambia Daily Mail, 2018) due to the stiff competition from both local and foreign players. For example, the Zambia National Commercial bank (Zanaco), one of the leading banks in Zambia, established a CSR office to specifically focus on CSR activities and issues. As a way of giving back to the community, the bank conducts financial education for its various customer groups and offers direct community support around various areas such as health, education and environment (Zanaco report, 2018). However, while there is a growing CSR interest by banks in Zambia, little is known on how bank customers perceive CSR activities especially its effect on buyer behaviour. A review of the literature indicates that the most of the research that has been done on CSR in Zambia has focused on the mining sector (e.g., Noyoo, 2010; Phiri et al., 2019; Cronje et al., 2017). As such, questions on whether bank customers appreciate CSR activities and how CSR affects buyer behaviour in developing economies in general and Zambia in particular remain unanswered.

Another important research gap in the literature is that the majority of the literature on CSR largely takes a stakeholder perspective (Chung et al., 2015) to the neglect of other theories such as the signaling theory. This study therefore draws insights from the stakeholder theory to examine the effect of CSR on customer satisfaction and customer loyalty and follows the signaling theory to examine the mediating role of trust. Stakeholder theory is essentially a theory about how business works at its best, and how it could work to improve and protect its various stakeholders (Freeman et al., 2010). The theory lists and describes stakeholders as individuals and groups who are affected by the company's actions and these include customers, suppliers, employees and investors. It is based on the understanding that the interests of groups are joint and that to create value; one must focus on how value gets created for each and every stakeholder (Freeman et al, 2010). As an example, firms incorporate corporate social responsibility into their marketing strategies to obtain customer recognition and loyalty as well as of other key stakeholders of the market (McWilliams and Siegel, 2001).

We draw insights from the signaling theory to postulate that CSR initiatives are tantamount to signals conveyed by a company to condense the uncertainty that can weigh upon consumers' purchasing decisions (Spence, 1973). Signaling is a notion that one party (termed the agent) plausibly conveys certain information about itself to another party (the principal) (Spence, 1973). According to this theory, high signal fit, that is the extent to which a signal corresponds with the unobservable signaler characteristic, is critical to the effectiveness of an informational cue (Connelly et al., 2011). Although rarely used in CSR studies, we find it reasonable to draw from the signaling theory to argue that building customer trust is a potential benefit for firms of embracing socially responsible practices (Montiel et al., 2012; Ramchander et al., 2012; Turban and Greening, 1996). The logic is that CSR practices may be a signal that reveals supplementary information to relevant stakeholders, customers in this case, to enhance predictability and trustworthiness of a company ( $\mathrm{Su}$ et al., 2016). Thus, from a customer's perspective, banks' CSR activities serve as an indicator of a bank's reliability and trustworthiness.

\subsection{Corporate Social Responsibility and Customer Satisfaction}

While researchers have considered the impact of CSR on myriad factors including financial performance, attitudes, intentions, emotional attachment, and brand identification, few studies have considered the relationship between CSR and customer satisfaction. Yet, the marketing literature recognizes customer 
satisfaction as a significant part of corporate strategy and a key driver of market value and long-term profitability. Customer satisfaction is defined as the overall assessment based on the customer's total purchase and consumption experience with a good or service overtime (Luo and Bhattacharya, 2006). It is also the result of the comparison between what the customer anticipates of a product or service and what is actually perceived or delivered (Walsh and Bartikowski, 2013). According to Chung et al. (2015), satisfaction is not only inherent in the attributes of a product or service itself but also in the consumer's perceptions of a company as a whole.

We draw insights from the stakeholder theory, which recognizes customers as one of the important stakeholders of a firm to argue that CSR has a positive effect on customer satisfaction. The logic is that being stakeholders, customers are likely to take keen interest in a firm's CSR activities to an extent that they are likely to be happy with a firm that presents itself as socially responsible toward society (He and $\mathrm{Li}, 2011$ ). A firm that engages in high CSR activities is likely to create a favourable image that enhances consumers' evaluations and attitudes towards a company. Also, the fact that customers evaluate firms as well as a firm's products in terms of CSR engagements, it is reasonable to expect that CSR activities in consumers' evaluation situation that are perceived more positively lead to higher customer satisfaction (Perez, 2013; Saeidi at al., 2015). Our argument is also consistent with prior studies that have found a positive relationship between CSR and customer satisfaction (e.g., Perez, 2013; Alafi and Hasoneh, 2012). Therefore we hypothesize that:

H1: There is a positive relationship between CSR and customer satisfaction.

\subsection{Corporate Social Responsibility and Loyalty}

Customer loyalty is a non-random predisposition exhibited by a customer to keep buying products from the same firm and associate positive images with the firm's products (Dick and Basu, 1994). Therefore, building a loyal customer base has become a major marketing goal as well as a crucial basis for developing a sustainable competitive advantage (Chung et al., 2015). Prior research has shown that customers consider a company's CSR initiatives when evaluating the company and its products (e.g., Chung et al., 2015; Dick and Basu, 1994; Choi and La, 2013; Pérez and del Bosque, 2015). To an extent that if customers are satisfied with a company's CSR activities and view a company to be socially responsible, they will increasingly be inclined to re-purchase its products or services and become loyal customers exhibiting strong customer goodwill. More specifically, studies by Choi and La (2013) and Pérez and del Bosque (2015) demonstrate that CSR commitment has a crucial role to play in generating loyalty among a company's customers. Hence, we suggest that

$\mathrm{H} 2$ : There is a positive relationship between CSR and customer loyalty.

\subsection{The Mediating Role of Trust}

Trust refers to values a firm shares with customers and these values, if upheld by the firm, instill confidence in an exchange and can a signal of a partner's reliability and integrity (Morgan and Hunt, 1994; Fatma et al., 2015). Coulter and Coulter (2002) conceptualize trust in a service provider as the perception of that service provider's confidentiality, honesty, integrity and high ethical standards. From the customer's point of view, trust has been understood as a customer's belief that the firm will perform in a manner consistent with their expectations (Park et al., 2014). It refers to common values a company shares with customers (Morgan and Hunt, 1994; Fatma et al., 2015). Thus, trust is a fundamental constituent in building and maintaining long-term relationships between a firm and its customers (Morgan and Hunt, 1994; Fatma et al., 2015; Pivato et al, 2008).

The perception that a company is ethical and responsible stimulates trust-based relationships founded on the belief that all exchange partners' actions will be credible beyond any contractual or legal constraints (Swaen and Chumpitaz, 2008). As such, a firm's socially responsible initiatives provide information about its character and values that help in building customer trust in the firm (Fatma et al., 2015). This 
study draws insights from the signaling theory to suggest that CSR activities create positive signals to stakeholders about the ethics and values of the company and this should lead to customer satisfaction and customer loyalty (Spence, 1973:1974). The logic is that firms that engage in CSR are more likely to be identified as trustees that act in the interests of the stakeholders, customers in this case, (Dirks and Ferrin, 2001, Rupp et al., 2006; Greser and Balmer, 2007; Kim, 2019) and this will lead to intensification of stakeholders' trust in the firm.

Our reasoning is in line with academic literature which identifies trust as a prerequisite for the satisfaction and creation and preservation of long-term relationships between a firm and its customers (Morgan and Hunt, 1994; Martinez and del Bosque, 2013; Choi and La, 2013; Fatma et al., (2015), especially in the context of intangible services marketing such as banks. The relationship marketing literature highlights the importance of trust as basic, fundamental and necessary to establish and develop long-term relationships element in order to implement a strategy of relationship marketing successfully (Bricci et al., 2016). In fact, researchers such as Bricci et al. (2016) and Elena and Jose (2001) have found trust to have a positive and direct effect on customer satisfaction. As Bricci et al (2016) inform, trust is considered by many studies of relationship marketing as essential to take into account in the development of lasting relationships and loyalty. So et al. (2013) agree with this view and add that trust is one of the most crucial and key component to building a relationship and thus is a strong determinant of customer loyalty.

While relatively many studies have tried to understand the trust-satisfaction and trust- loyalty links as they seem to be important relationships in the field of marketing (Furnell and Karweni, 1999; Vlachos et al., 2009), very few studies have examined the mediating role of trust on the CSR-customer satisfaction and CSR-Customer loyalty relationships (Choi and La, 2013; Martinez and del Bosque, 2013). We argue that CSR initiatives are likely to have a direct influence on consumer trust and affect perceptions about the quality of the products/services that a company is offering (Swaen and Chumpitaz, 2008) and in turn enhance customer satisfaction and customer loyalty. Our argument is in line with Fatma et al., (2015) study where trust was found to mediate the relationship between CSR and corporate reputation and brand equity. Therefore, based on these ideas about trust, we propose the following hypotheses:

H3a. CSR positively influences customer satisfaction through trust.

H3b. CSR positively influences Customer loyalty through Trust.

\section{Figure 1- Conceptual Model}

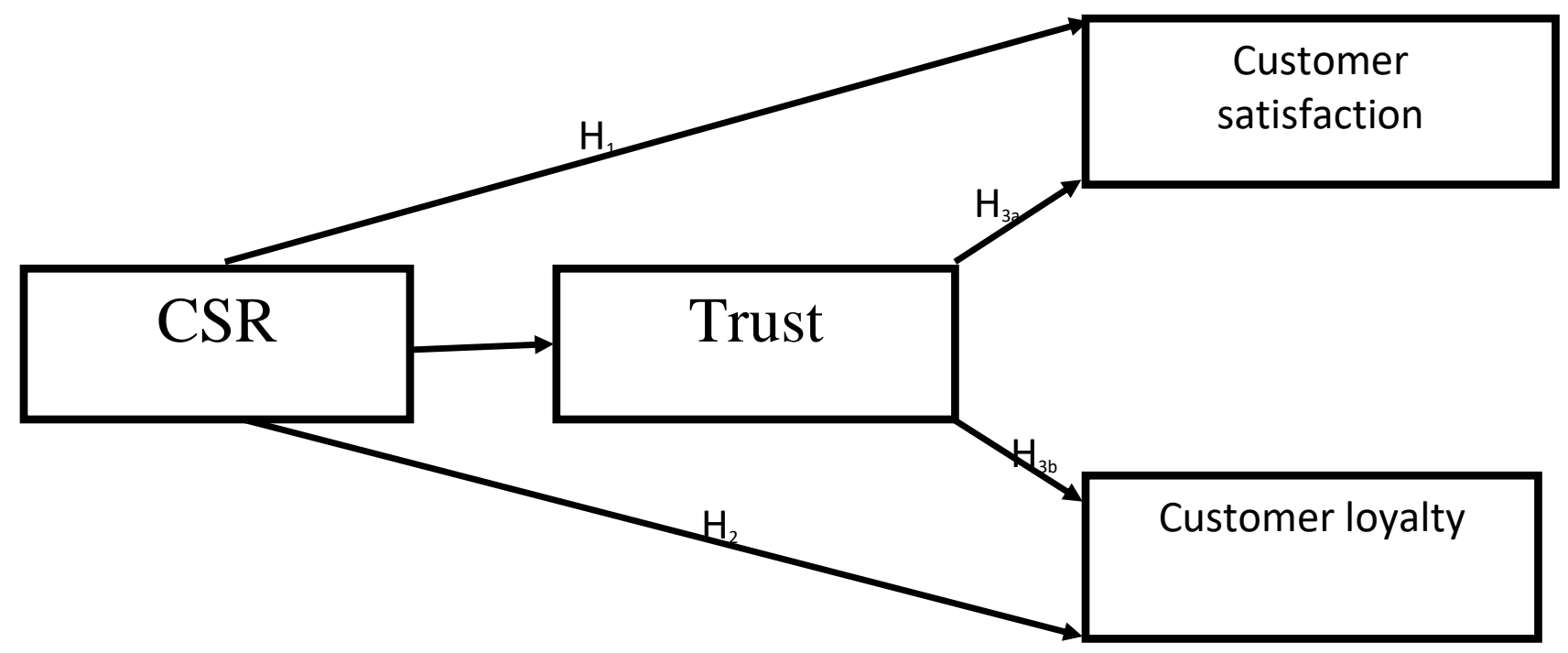




\section{Methodology}

\subsection{Sample and Data Collection}

To test the conceptual model, data was collected from student bank customers at the Copperbelt University in Kitwe, Zambia. The banking sector remains critical in the economic development of most countries through its ability to gather deposits from savers and distribute it to individuals and firms that need it for investment and production (Ghosh, 2017). In Zambia, this sector is growing at a rapid rate and is experiencing stiff competition from both local and foreign players (Simpasa et al., 2015). As such, a growing number of banks have become more customer focused and are seeking ways of building long lasting relationships with customers, a situation which was not the case before. It is not surprising that most banks in Zambia have become more interested in and have embraced corporate social responsibility (CSR) in an effort to influence positive customer perception and achieve sustainable competitive advantage (Zambia Daily Mail, 2018). Kitwe is not only the second largest city in Zambia in terms of size and population but also commercially rich with almost all banks in Zambia having at least a branch. The Copperbelt University is the second largest public university in Zambia with most of its students being on the government scholarship scheme, which allows them to receive a monthly stipend. As such, most of the students at the university need and use bank services.

We targeted students who had at least one bank account active at the time of answering the questionnaire. These student bank customers were found at the university, in the lodging rooms, classroom and corridors. Being bank customers, it was appropriate to understand students' reactions to the banks' involvement in uplifting the living standards of people in communities in which they (banks) operate. In addition, it was easier to generate information from active student bank customers because then the respondents had a service in mind. Therefore, a structured questionnaire was used and administered to students that met the following requirements: (1) they were registered students at the Copperbelt University; (2) the students had an account with one of the banks; and (3) students were aware of the banks CSR activities. Using the Raosoft online calculator with an estimated population of 20,000 registered students (based on records from the University's academic office), the minimum required representative sample size of 377 was derived. A simple random sampling technique was used to select participants for the survey. Of the 377 questionnaires face-to-face administered, 348 useable questionnaires were returned (response rate of 92.3\%). This response rate is impressive and confirms Saunders and Lewis' (2012) argument that the face-to-face approach is usually associated with high response rate. The response rate is also comparable to previous student research studies (e.g., Mwiya et al., 2018). The sample profile is given in table 1 below.

\section{Table 1: Sample Profile}

\begin{tabular}{|l|l|l|l|l|}
\hline Characteristic & \multicolumn{1}{|c|}{ Description } & Frequency & Percent & \multicolumn{1}{|c|}{$\begin{array}{c}\text { Cumulative } \\
\text { Percent }\end{array}$} \\
\hline \multirow{3}{*}{ Gender } & Male & 198 & 56.9 & 56.9 \\
\cline { 2 - 5 } & Female & 150 & 43.1 & 100.0 \\
\hline \multirow{5}{*}{ Age Group } & $16-20$ & 45 & 12.9 & 12.9 \\
\cline { 2 - 5 } & $21-25$ & 290 & 83.3 & 96.2 \\
\cline { 2 - 5 } & Above 25 & 13 & 3.8 & 100.0 \\
\hline \multirow{5}{*}{ Saculty } & School of Business & 159 & 45.7 & 45.7 \\
\cline { 2 - 5 } & School of Engineering & 95 & 27.3 & 73.0 \\
\cline { 2 - 5 } & School of Mathematics and & 61 & 17.5 & 90.5 \\
\cline { 2 - 5 } & Natural Sciences & & & \\
\cline { 2 - 5 } & School of Built Environment & 20 & 5.7 & 96.2 \\
\cline { 2 - 5 } & School of Natural Resources & 13 & 3.8 & 100.0 \\
\hline
\end{tabular}


The resulting sample profile shows $56.9 \%$ male and $43.1 \%$ female. The majority of the respondents were aged between 21 and 25. The average age of between 21 and 25 in the sample is typical of university students in Zambia (Mwiya, et al., 2018). 46\% of the respondents were from the School of Business while School of Natural Resources had the least respondents (4\%). The School of Business offers business courses such as banking, finance and marketing in which corporate social responsibility issues are discussed. Therefore, we are confident that the majority of the students surveyed have an understanding and knowledge of the study at hand.

\subsection{Measures}

We derived items used to measure the theoretical constructs from an extensive review of extant literature. This does not only assure us of content validity but also allows for comparison of results with prior studies (Thompson, 2009). However, the items' wording was adapted, where necessary, to reflect customers' understanding of the constructs and as applied to the banking sector based on the pilot test of the questionnaire. Each item was measured using a 5-point Likert scale, ranging from strongly disagree (1) to strongly agree (5). Table 2 displays details of the measures used and their sources.

We adapted our CSR measures from Brown and Dacin (1997). Specifically, the instrument measured the extent to which customers perceived their bank to be socially responsible. For example, customers were asked the following question: this bank shows it's committed towards society by improving the welfare of the communities in which it operates. Trust was measured with 5 items adapted from Morgan and Hunt (1994) and Sirdeshmukh et al. (2002). The measures tap the extent to which customers trust their respective banks. Sample items include 'The services of this bank make me feel a sense of security. We measured customer satisfaction with 4 items drawn from the original 6 items used by Cronin et al. (2000). The sample items include: 'I think I did the right thing when I joined this bank'. Customer loyalty was measured using 4 items provided by Zeithaml et al. (1996) and Sirdeshmukh et al. (2002). An example of the items is 'I shall continue considering this one as my main bank in the next few years'.

The instrument also included questions that sought demographic information such as age, gender, the program the student is enrolled in, and the name of the bank that the student participant mostly used. In fact, age and gender were used as control variables in line with previous studies (e.g., Mwiya et al., 2018). Age was log transformed while gender was measured as a dichotomous variable coded such that 1 was for female and 2 male.

\subsection{Reliability and Validity Test of the Instrument}

We used principal component analysis with varimax rotation to examine the factor structure of the constructs and to establish construct validity. Results indicate that all the scale items were adequate for measuring the latent variables. For example, Kaiser-Meyer-Olkin measure of sampling adequacy at 0.915 was well above the minimum 0.50 threshold and Bartlett's Test of Sphericity was significant (Chi-Square $=3013.003, \mathrm{df}=120$, sig. $<0.001$ ) (Pallant et al., 2016). In addition, all the four main factors with the Eigen values above 1.0 arose and the four factors altogether explained a total of $67.66 \%$ of the variance. Furthermore, all scales showed discriminant validity with each scale item loading on the respective factor and there were no cross loadings. Reliability tests for internal consistency of the respective items in the four latent variables also yielded satisfactory Cronbach alpha scores of above Bagozzi and Yi's (2012) 0.7 threshold. Specifically, the Cronbach alpha values for CSR, trust, satisfaction and loyalty are 0.744, $0.853,0.863$ and 0.786 respectively as shown in see Table 2 . 
Table 2: Factor Analysis and Reliability Results

\begin{tabular}{|c|c|c|c|c|}
\hline \multirow[b]{2}{*}{ Items } & \multicolumn{4}{|c|}{ Components } \\
\hline & 1 & 2 & 3 & 4 \\
\hline $\begin{array}{l}\text { CSR } \\
\text { This bank protects the environment } \\
\text { This bank shows it's committed towards society by improving the welfare } \\
\text { of the communities in which it operates. } \\
\text { The bank directs part of its budget to donations to social causes. } \\
\text { Trust } \\
\text { The services of this company make me feel a sense of security. } \\
\text { I trust on the quality of this bank. } \\
\text { I trust the quality of the hiring process of this bank } \\
\text { This bank is interested in its customers. } \\
\text { This bank is honest with its customers. } \\
\text { Customer Satisfaction } \\
\text { My choice to be a part of this bank was a wise one. } \\
\text { I think I did the right thing when I joined this bank. } \\
\text { This bank offers exactly when I need for my banking services. } \\
\text { Overall, I am satisfied with the services of this bank. } \\
\text { Customer Loyalty } \\
\text { I usually use this bank as my first choice compared to other banks. } \\
\text { It would be costly in terms of money, time and effort to end the relationship } \\
\text { with this bank. } \\
\text { I shall continue considering this one as my main bank in the next few years. } \\
\text { I would recommend this bank if somebody asked my advice. }\end{array}$ & $\begin{array}{l}0.786 \\
0.823 \\
0.762\end{array}$ & $\begin{array}{l}0.815 \\
0.809 \\
0.844 \\
0.817 \\
0.825\end{array}$ & $\begin{array}{l}0.808 \\
0.804 \\
0.852 \\
0.835\end{array}$ & $\begin{array}{l}0.722 \\
0.813 \\
\\
0.681 \\
0.709 \\
\end{array}$ \\
\hline Cronbach Alpha & 0.744 & 0.853 & 0.863 & 0.786 \\
\hline
\end{tabular}

\subsection{Results}

\subsection{Correlations results}

Data were analysed in phases using SPSS. First, Pearson's correlation coefficients were computed to establish whether there was significant linear relationships among CSR, trust, satisfaction, and loyalty before carrying out the hierarchical regression analysis. Table 3 indicates the means, standard deviations of the variables including of the control variables (age and gender) as well as correlations among all these variables. We followed Pallant et al., (2016) to conclude that multicollinearity is not an issue in this study as the all the correlations are less than 0.80 .

\section{Table 3. Mean, Standard Deviation and Correlation Matrix}


Std.

\begin{tabular}{lrrrrrrrr}
\multicolumn{1}{c}{ Variable } & Mean & Deviation & $\mathrm{N}$ & 1 & 2 & 3 & 4 & 5 \\
\hline 1 Satisfaction & 3.4978 & 0.88546 & 348 & - & & & & \\
2 Loyalty & 3.4411 & 0.91602 & 348 & $.744^{* *}$ & - & & & \\
3 Actual age & 22.46 & 1.837 & 348 & 0.024 & 0.020 & - & & \\
4 Gender & 0.4310 & 0.49593 & 348 & 0.015 & 0.037 & $-273^{* *}$ & - & \\
5 Trust & 3.4494 & 0.83723 & 348 & $.704^{* *}$ & $.687^{* *}$ & 0.047 & 0.003 & - \\
6 Corporate Social Responsibilty & 3.1360 & 0.81454 & 348 & $.400^{* *}$ & $.400^{* *}$ & -0.006 & 0.023 & $.482^{* *}$ \\
\hline${ }^{* *}$ significant at p<0.01 & & & & & & & &
\end{tabular}

From Table 3, it can be seen that there is a link between loyalty and satisfaction which is strong and significant $(\mathrm{r}=.744, \mathrm{p}<0.01)$. Other important relations worth noting are those between trust and satisfaction $(\mathrm{r}=.704, \mathrm{p}<0.01)$ and trust and loyalty $(\mathrm{r}=.687, \mathrm{p}<0.01)$. The table also shows positive correlations of CSR and satisfaction $(r=.400)$, CSR and Loyalty $(r=0.401)$ and CSR and trust $(r=.482)$. It is also important to note that the control variables, actual age and gender, are negatively correlated. However, there is an insignificant correlation between the control variables and the other variables.

\subsection{Regression Results}

Next, hierarchical regression analysis was conducted to test the hypotheses. To start with, the effect of the control variables, age and gender, on the dependent variables satisfaction, loyalty and trust, respectively was measured in Models 1a, 2a and 3a. Then Models 1b, 2b and 3b were examined measuring the effect of the control variables and the direct effects on the dependent variables. From Table 4, it can be seen that CSR is not significantly related to customer satisfaction $(.079,1.806)$ and as such $\mathrm{H} 1$ of a direct relationship is rejected. H2 is accepted as CSR has a positive and significant effect on loyalty (.090, $2.020)$. Although not hypothesized, CSR has a positive effect on trust $\left(.482,10.213^{*}\right)$. Trust has a positive and significant relation on customer satisfaction $\left(.666,15.283^{*}\right)$ and customer loyalty $\left(.643,14.437^{*}\right)$, respectively, suggesting possible mediating effects of trust. The next section gives further test results of this mediation relationship.

Table 4. Regression Results

\begin{tabular}{|l|l|l|l|l|l|l|}
\hline $\begin{array}{l}\text { Independent } \\
\text { Variable }\end{array}$ & Model 1a & Model 1b & Model 2a & Model 2b & Model 3a & Model 3b \\
\hline & $\begin{array}{l}\text { Dependent } \\
\text { variable: } \\
\text { Customer } \\
\text { satisfaction }\end{array}$ & $\begin{array}{l}\text { Dependent } \\
\text { variable: } \\
\text { Customer } \\
\text { satisfaction }\end{array}$ & $\begin{array}{l}\text { Dependent } \\
\text { variable: } \\
\text { Customer } \\
\text { loyalty }\end{array}$ & $\begin{array}{l}\text { Dependent } \\
\text { variable: } \\
\text { Customer } \\
\text { loyalty }\end{array}$ & $\begin{array}{l}\text { Dependent } \\
\text { variable: } \\
\text { Trust }\end{array}$ & $\begin{array}{l}\text { Dependent } \\
\text { variable: } \\
\text { Trust }\end{array}$ \\
\hline & Beta, t & Beta, t & Beta, t & Beta, t & Beta, t & Beta, t \\
\hline age & $.031, .546$ & $-.004,-.104$ & $.033, .584$ & $.000,-.020$ & $.052, .929$ & $.052,1.050$ \\
\hline gender & $.024, .673$ & $.011, .265$ & $.046, .822$ & $.033, .814$ & $.017, .302$ & $.006, .113$ \\
\hline CSR & & $.079,1.806$ & & $.090,2.020^{*}$ & & $.482,10.213^{*}$ \\
\hline Trust & & $.666,15.283^{*}$ & & $.643,14.437^{*}$ & & \\
\hline
\end{tabular}




\begin{tabular}{|c|c|c|c|c|c|c|}
\hline $\mathbf{R}$ & .033 & .708 & .049 & .692 & .050 & .484 \\
\hline R Square & .001 & .501 & .002 & .479 & .003 & .235 \\
\hline $\begin{array}{ll}\text { Adjusted } & \text { R } \\
\text { Square } & \\
\end{array}$ & -.005 & .495 & -.003 & .473 & -.003 & .228 \\
\hline F- Statistic & .189 & 86.021 & .408 & 78.786 & .433 & 35.142 \\
\hline
\end{tabular}

\subsection{Mediation}

We followed Baron and Kenny (1986)'s procedure which explains that a variable's mediation must meet three conditions: 1 . the independent variable is a significant predictor of both the dependent and mediator variables; 2 . The mediator variable is a significant predictor of the dependent variable, and 3 . The effects of the independent variable on the dependent variable are reduced when the mediator variable is added to the regression model. Mediation is completely accepted if the effect of the independent variable on the dependent variable is no longer significant when the mediator variable is added. On the other hand, mediation is partially accepted if the effect of the independent variable decreases, but remains significant (Baron and Kenny, 1986; Preacher and Hayes, 2004). The analysis was done using a three-step procedure suggested by Baron and Kenny (1986) and the three conditions were met. However, considering the shortcomings inherent in Baron and Kenny's method in that it does not directly test for the mediation effect; has higher type 1 error rates and assumes normal distribution of errors (Preacher and Hayes, 2008; Swickert et al., 2012; Zhao et al., 2010), the Sobel statistical test was performed to determine whether the association between independent and dependent variables were significantly reduced when a mediator variable was included (Soulsby and Bennett, 2015; Zhao et al., 2010; Preacher and Hayes, 2008).This technique directly tests the indirect effect between the independent and dependent variables through a mediator variable and is recommended by scholars (Cardon et al., 2009; Goethner et al., 2009; Khedhaouria et al., 2015).

Results of the Sobel test in Table 5 show that the effect of the independent variable CSR on the mediating variable, trust, is positive and significant $(\mathrm{a}=0.495, \mathrm{p}<0.01)$. The table also indicates that trust's influence on customer satisfaction is significant $(b=0.704, \mathrm{p}<0.01)$. Further, the table indicates that CSR has a total effect on customer satisfaction which is significant $(c=0.435, \mathrm{p}<0.01)$. However, the effect of CSR on satisfaction decreases and is not significant when trust is added to the equation $\left(c=0.435\right.$ to $\left.c^{\prime}=0.086\right)$. The mediation effect is significant $(\mathrm{Z}=8.552, \mathrm{p}<0.01)$ and we can therefore deduce from the Sobel test results that trust fully mediates the relationship between CSR and satisfaction.

Furthermore, Sobel test results show that trust's influence on customer loyalty is positive and significant $(b=0.703, p<0.01)$. The CSR also has a significant positive direct effect on customer loyalty $\left(c^{\prime}=0.102\right.$, $\mathrm{p}<0.05)$. CSR's total effect on customer loyalty is also significant $(c=0.45, p<0.01)$ and so is the mediation effect $(\mathrm{Z}=8.374$, $\mathrm{p}<0.01)$. Although the effect of CSR on loyalty decreased when trust was added to the equation, the CSR-loyalty relationship remained significant and we can therefore conclude that trust partially mediates the CSR-customer loyalty relationship.

\section{Table 5. Sobel Mediation Analysis}

\begin{tabular}{|c|c|c|c|c|c|c|c|c|c|}
\hline Hypothesis & $\begin{array}{l}\text { Independent } \\
\text { variable }\end{array}$ & $\begin{array}{l}\text { Mediating } \\
\text { variable }\end{array}$ & $\begin{array}{l}\text { Dependent } \\
\text { variable }\end{array}$ & $\begin{array}{l}\text { Effect of } \\
\text { IV on } \\
\text { mediator } \\
\text { (a) }\end{array}$ & $\begin{array}{l}\text { Unique } \\
\text { effect of } \\
\text { mediator } \\
\text { (b) }\end{array}$ & $\begin{array}{l}\text { Direct } \\
\text { effect } \\
\text { (C') }\end{array}$ & $\begin{array}{l}\text { Total } \\
\text { effect } \\
\text { (c) }\end{array}$ & $\begin{array}{l}\text { Sobel } \\
\text { Test } \\
\text { (Z) }\end{array}$ & $\begin{array}{l}\text { Degree of } \\
\text { mediation }\end{array}$ \\
\hline $3 a$ & CSR & Trust & Satisfaction & $0.495 * *$ & $0.704 * *$ & 0.086 & $0.435^{* *}$ & $8.552 * *$ & Full \\
\hline $3 b$ & CSR & Trust & Loyalty & $0.495 * *$ & $0.703^{* *}$ & $0.102 *$ & $0.45 * *$ & $8.374 * *$ & Partial \\
\hline
\end{tabular}




\section{Discussion}

Based on the correlation analysis, the findings of this study suggest that there is a link between the independent variable and each of the dependent variables. Specifically, results show that CSR positively and significantly correlates with both customer satisfaction and customer loyalty. This resonates with findings by prior studies such as Chung et al. (2015), Perez-Batres et al. (2012), Alafi and Hasoneh (2012) and $\mathrm{He}$ and $\mathrm{Li}$ (2011). Hence, we stand to reason that firms that engage in CSR activities are likely to enhance the satisfaction of their customers as well as build customer loyalty.

However, our multiple regression analysis results indicate that while CSR remains positively related with customer loyalty, CSR is not significantly related to customer satisfaction when trust is introduced. Interestingly, trust is found to be positively related to CSR, customer satisfaction and customer loyalty, suggesting mediation. Further, Sobel mediation test results confirm that trust fully mediates the relationship between CSR and customer satisfaction while a partial mediation relationship between CSR and customer loyalty is established.

Our study contributes to the business strategy literature in several ways. First, while the majority of the available evidence point to a positive association between CSR and determinants of company performance such as monetary performance, personnel commitment and corporate identity, our study is among a few studies (e.g., Chung et al., 2015; Perez-Batres et al., 2012; Alafi and Hasoneh, 2012; He and $\mathrm{Li}, 2011$ ) to empirically demonstrate that bank CSR engagement is linked to positive customer outcomes such as customer satisfaction and loyalty.

Second, by examining trust as a mediator, this research helps to clarify earlier CSR studies that have advocated for a direct link between CSR and customer satisfaction (e.g., Luo and Bhattacharya, 2006; Alafi and Hasoneh, 2012; Chung et al., 2015; Chung et al., 2015; Perez-Batres et al., 2012; He and Li, 2011). Our study extends these studies by providing evidence that the CSR-customer satisfaction and loyalty relationship is more complex than has previously been found. This study reveals that CSR activities influence customer satisfaction and loyalty directly and indirectly through trust. Consistent with the signaling theory our study confirms that CSR initiatives can be used as signals sent by a company to reduce the uncertainty that can weigh upon consumers' purchasing decisions by enhancing trust (Van Knippenberg and Sleebos, 2006).

Although prior works have noted that CSR affects various kinds of consumer responses, studies that examine trust as one of the outcomes are rare in the literature. As such, this study extends the research stream on trust by uncovering CSR as an antecedent that can increase or reduce a company's trustworthiness in the eyes of its customer to create satisfaction and loyalty. Given the intangible and risky nature of bank services, trust is a fundamental component in building and maintaining long term relationships between customers and bank service providers (Morgan and Hunt, 1994; Fatma et al., 2015). As suggested by CSR scholars (Brown and Dacin, 1997; Connelly et al., 2011; Homburg et al., 2013; Swaen and Chumpitaz, 2008; Martinez and del Bosque, 2013; He and Li, 2011) CSR initiatives provide information about the character and values of a company and helps build trust among customers and in turn affect perceptions about the quality of the products/services that a company is offering and enhance customer satisfaction and loyalty.

Third, while CSR has been relatively more researched in developed countries, not much has been done on the subject in developing countries. Therefore, this study extends the frontiers of strategy and CSR literatures to a context previously less-examined, a developing Sub- Saharan African economy. By testing the conceptual model on Zambian-based bank customers, the study provides evidence of the applicability of not only the CSR phenomenon but also Western developed and validated measures beyond the 
developed economy context and is a timely response to the recent appeal by Jamali and Karam (2018) to CSR researchers to embrace developments in such regional settings to advance the development of theory and practice.

Last but not least, traditionally, the few available studies on CSR in Zambia have largely focused on mining firms and financial performance to the neglect of CSR in other sectors such as banks (e.g., Noyoo, 2010; Phiri et al., 2019) and customer outcomes. As such, very little is known about how CSR is perceived by bank customers located in developing Sub-Saharan markets and bank managers have no basis for developing CSR strategies and setting resource allocation priorities to improve trust, customer satisfaction and Loyalty. Our study highlights that CSR is an important strategic tool for banks not only because of the intense competition and low differentiating factors of the services provided but also because of the intangibility and risky nature on financial service transactions, which call for service providers to continuously send positive signals to build customer trust and in turn enhance customer satisfaction and loyalty.

\section{Managerial Implications}

In this rapidly changing market conditions, there is need for managers to formulate business strategies that allow easy adaptation and maintenance as well as improvement of their competitive position. This study provides evidence that creation of a business strategy based on the CSR concept is an important opportunity for differentiation and achieving positive customer outcomes. Our study shows that customers are more likely to trust a bank that engages in CSR activities and in turn be more satisfied with the services provided by the bank and become loyal customers. As such, banks stand to benefit, by being trusted, having satisfied and loyal customers if they give back to the society in which they operate. Managers are therefore advised to pay attention and invest more in CSR activities as customers consider these activities when making purchase decisions.

\section{Limitations and Direction for Future Research}

While this study helps bring understanding of customers' perceptions of banks' CSR engagements in a context that remains largely under-researched, some limitations can be noted from the study on which future research can build on. The fact that the research strategy is cross-sectional and quantitative in nature means that the measurement, collection and analysis of data emphasized on quantification (use of numbers) and not gaining deeper understanding of the underlying reasons on customers' perceptions of CSR. As such, future research can take on the exploratory qualitative strategy in order to uncover trends in thought and gather in-depth viewpoints held by customers about their banks' CSR activities.

Additionally, since this study used trust as a mediating variable, further studies can look into other variables such as word-of-mouth and customer identification. Also, examining how the variables interact to affect the customer outcomes is another direction for future research. This will allow for a broader perceptive to be taken to provide a better understanding of how the factors could complement each other to enhance customer satisfaction and loyalty.

Finally, further research should aim at conducting a longitudinal study to replicate and extend the research scope on the study constructs. This could provide well-grounded and better-nuanced results. The fact that CSR is fully mediated by trust in this study could be that CSR outcomes need to be studied over a longer period of time. Thus, conducting this study across time could help increase the precision of the findings and enable stronger statistical inferences to be made.

\section{References}

Aguilera, R. V., Rupp, D. E., Williams, C. A., \& Ganapathi, J. (2007). Putting the S back in corporate social responsibility: A multilevel theory of social change in organizations. Academy of 
Management Review, 32(3), 836-863.

Ailawadi, K. L., Neslin, S. A., Luan, Y. J., \& Taylor, G. A. (2014). Does retailer CSR enhance behavioral loyalty? A case for benefit segmentation. International Journal of Research in Marketing, 31(2), 156-167.

Alafi, K., \& Hasoneh, A. B. (2012). Corporate social responsibility associated with customer satisfaction and financial performance a case study with Housing Banks in Jordan. International Journal of Humanities and Social Science, 2(15), 102-115.

Aupperle, K. E., Carroll, A. B., \& Hatfield, J. D. (1985). An empirical examination of the relationship between corporate social responsibility and profitability. Academy of Management Journal, 28(2), 446-463.

Bagozzi, R. P., \& Yi, Y. (2012). Specification, evaluation, and interpretation of structural equation models. Journal of the Academy of Marketing Science, 40(1), 8-34.

Baron, R. M., \& Kenny, D. A. (1986). The moderator-mediator variable distinction in social psychological research: Conceptual, strategic, and statistical considerations. Journal of Personality and Social Psychology, 51(6), 1173.

Bondy, K., Moon, J., \& Matten, D. (2012). An institution of corporate social responsibility (CSR) in multi-national corporations (MNCs): Form and implications. Journal of Business Ethics, 111(2), 281-299.

Branco, M. C., \& Rodrigues, L. L. (2008). Factors influencing social responsibility disclosure by Portuguese companies. Journal of Business Ethics, 83(4), 685-701.

Bricci, L., Fragata, A., \& Antunes, J. (2016). The effects of trust, commitment and satisfaction on customer loyalty in the distribution sector. Journal of Economics, Business and Management, , 4(2), 173-177.

Bromiley, P. \& Marcus A. (1989). The Deterrent to Dubious Corporate Behavior: Profitability, Probability, and Safety Recalls. Strategic Management Journal 10(3), 233-250.

Brown, T. J., \& Dacin, P. A. (1997). The company and the product: Corporate associations and consumer product responses. Journal of Marketing, 61(1), 68-84.

Cardon, M. S., Wincent, J., Singh, J., \& Drnovsek, M. (2009). The nature and experience of entrepreneurial passion. Academy of Management Review, 34(3), 511-532.

Carroll, A. B. (1999). Corporate social responsibility: Evolution of a definitional construct. Business \& Society, 38(3), 268-295.

Carroll, A. B. (2016). Carroll's pyramid of CSR: taking another look. International Journal of Corporate Social Responsibility, 1(1), 3.

Carroll, A. B., \& Shabana, K. M. (2010). The business case for corporate social responsibility: A review of concepts, research and practice. International Journal of Management Reviews, 12(1), 85-105.

Choi, B., \& La, S. (2013). The impact of corporate social responsibility (CSR) and customer trust on the restoration of loyalty after service failure and recovery. Journal of Services Marketing, 27(3), 223233.

Choongo, P. (2017). A longitudinal study of the impact of corporate social responsibility on firm performance in SMEs in Zambia. Sustainability, 9(8), 1300.

Chung, K. H., Yu, J. E., Choi, M. G., \& Shin, J. I. (2015). The effects of CSR on customer satisfaction and loyalty in China: the moderating role of corporate image. Journal of Economics, Business and Management, 3(5), 542-547.

Collier, J., \& Esteban, R. (2007). Corporate social responsibility and employee commitment. Business Ethics: A European Review, 16(1), 19-33.

Cone, C.L., Feldman, M.A. and DaSilva, A.T. (2003), "Causes and effects", Harvard Business Review, Vol. 81 No. 7, pp. 95-101.

Connelly, B. L., Certo, S. T., Ireland, R. D., \& Reutzel, C. R. (2011). Signaling theory: A review and assessment. Journal of Management, 37(1), 39-67. 
Journal of Accounting and Finance in Emerging Economies

Vol.5, No 2, December 2019

Coulter, K. S., \& Coulter, R. A. (2002). Determinants of trust in a service provider: the moderating role of length of relationship. Journal of Services Marketing, 16(1), 35-50.

Cronin Jr, J. J., Brady, M. K., \& Hult, G. T. M. (2000). Assessing the effects of quality, value, and customer satisfaction on consumer behavioral intentions in service environments. Journal of Retailing, 76(2), 193-218.

Cronjé, F., Reyneke, S., \& Chenga, C. (2017). Corporate Social Responsibility in the Zambian mining sector: an overview of three distinctive operational eras. Koers, 82(1), 1-18.

Davis, K. (1975). Blomstrom. R, Business and Society: Environment and Responsibility ( $3^{\text {rd }}$ ed.). New York: McGraw-Hill Book Company.

Dick, A. S., \& Basu, K. (1994). Customer loyalty: toward an integrated conceptual framework. Journal of the Academy of Marketing Science, 22(2), 99-113.

Dirks, K. T., \& Ferrin, D. L. (2001). The role of trust in organizational settings. Organization Science, 12(4), 450-467.

Elena, D. B., \& Jose, L. M. A. (2001). Brand trust in the context of consumer loyalty. European Journal of Marketing, 35(11-12), 1238-1258.

Fatma, M., Rahman, Z., \& Khan, I. (2015). Building company reputation and brand equity through CSR: the mediating role of trust. International Journal of Bank Marketing, 33(6), 840-856.

Fombrun, C. J., Gardberg, N. A., \& Sever, J. M. (2000). The Reputation Quotient SM: A multistakeholder measure of corporate reputation. Journal of Brand Management, 7(4), 241-255.

Freeman, R. E., Harrison, J. S., Wicks, A. C., Parmar, B. L., \& De Colle, S. (2010). Stakeholder theory: The state of the art. Cambridge University Press.

Friedman, M. (1970). The Social Responsibility of Business is to Increase its Profits. New York Times Magazine. September 13, 1970

Furnell, S. M., \& Karweni, T. (1999). Security implications of electronic commerce: a survey of consumers and businesses. Internet Research, 9(5), 372-382.

George, G., Corbishley, C., Khayesi, J. N., Haas, M. R., \& Tihanyi, L. (2016). Bringing Africa in: Promising directions for management research.

Ghosh, S. (2017). Corporate governance reforms and bank performance: evidence from the Middle East and North Africa. Corporate Governance: The International Journal of Business in Society, 17(5), 822-844.

Goethner, M., Obschonka, M., Silbereisen, R. K., \& Cantner, U. (2009). Approaching the agora: Determinants of scientists' intentions to purse academic entrepreneurship (No. 2009, 079). Jena economic research papers.

Graves, S. B., \& Waddock, S. A. (1994). Institutional owners and corporate social performance. Academy of Management Journal, 37(4), 1034-1046.

Grayson, D., \& Hodges, A. (2017). Corporate social opportunity!: Seven steps to make corporate social responsibility work for your business. Routledge.

Harrison, J. S., Bosse, D. A., \& Phillips, R. A. (2010). Managing for stakeholders, stakeholder utility functions, and competitive advantage. Strategic Management Journal, 31(1), 58-74.

He, H., \& Li, Y. (2011). CSR and service brand: The mediating effect of brand identification and moderating effect of service quality. Journal of Business Ethics, 100(4), 673-688.

Homburg, C., Stierl, M., \& Bornemann, T. (2013). Corporate social responsibility in business-to-business markets: How organizational customers account for supplier corporate social responsibility engagement. Journal of Marketing, 77(6), 54-72.

Hoskisson, R. E., Eden, L., Lau, C. M., \& Wright, M. (2000). Strategy in emerging economies. Academy of Management Journal, 43(3), 249-267.

Jamali, D., \& Karam, C. (2018). Corporate social responsibility in developing countries as an emerging field of study. International Journal of Management Reviews, 20(1), 32-61.

Khan, A., Muttakin, M. B., \& Siddiqui, J. (2013). Corporate governance and corporate social responsibility disclosures: Evidence from an emerging economy. Journal of Business 
Ethics, 114(2), 207-223.

Khedhaouria, A., Gurău, C., \& Torrès, O. (2015). Creativity, self-efficacy, and small-firm performance: the mediating role of entrepreneurial orientation. Small Business Economics, 44(3), 485-504.

Kiessling, T., Isaksson, L., \& Yasar, B. (2016). Market orientation and CSR: Performance implications. Journal of Business Ethics, 137(2), 269-284.

Kim, H. R., Lee, M., Lee, H. T., \& Kim, N. M. (2010). Corporate social responsibility and employeecompany identification. Journal of Business Ethics, 95(4), 557-569.

Kim, S. (2019). The process model of corporate social responsibility (CSR) communication: CSR communication and its relationship with consumers' CSR knowledge, trust, and corporate reputation perception. Journal of Business Ethics, 154(4), 1143-1159.

Korschun, D., Bhattacharya, C. B., \& Swain, S. D. (2014). Corporate social responsibility, customer orientation, and the job performance of frontline employees. Journal of Marketing, 78(3), 20-37.

Kotler, P., \& Lee, N. (2005). Best of breed: When it comes to gaining a market edge while supporting a social cause,"corporate social marketing” leads the pack. Social Marketing Quarterly, 11(3-4), 91103.

Kotler, P., \& Lee, N. (2005). Best of breed: When it comes to gaining a market edge while supporting a social cause,"corporate social marketing” leads the pack. Social marketing quarterly, 11(3-4), 91103.

Kotler, P., \& Lee, N. (2008). Corporate social responsibility: Doing the most good for your company and your cause. John Wiley \& Sons.

Lam, J. S. L., \& Lim, J. M. (2016). Incorporating corporate social responsibility in strategic planning: case of ship-operating companies. International Journal of Shipping and Transport Logistics, 8(3), 273-293.

Lee, E. M., Park, S. Y., \& Lee, H. J. (2013). Employee perception of CSR activities: Its antecedents and consequences. Journal of Business Research, 66(10), 1716-1724.

Lichtenstein, D. R., Drumwright, M. E., \& Braig, B. M. (2004). The effect of corporate social responsibility on customer donations to corporate-supported nonprofits. Journal of Marketing, 68(4), 16-32.

Lungu, J., \& Shikwe, A. (2006). Corporate social responsibility practices in small-scale mining on the Copperbelt. Ndola: Mission Press.

Luo, X., \& Bhattacharya, C. B. (2006). Corporate social responsibility, customer satisfaction, and market value. Journal of Marketing, 70(4), 1-18.

Maignan, I., \& Ferrell, O. C. (2004). Corporate social responsibility and marketing: An integrative framework. Journal of the Academy of Marketing Science, 32(1), 3-19.

Martínez, P., \& del Bosque, I. R. (2013). CSR and customer loyalty: The roles of trust, customer identification with the company and satisfaction. International Journal of Hospitality Management, 35, 89-99.

McDonald, L. M., \& Rundle-Thiele, S. (2008). Corporate social responsibility and bank customer satisfaction: a research agenda. International Journal of Bank Marketing, 26(3), 170-182.

McGuire, J. B., Sundgren, A., \& Schneeweis, T. (1988). Corporate social responsibility and firm financial performance. Academy of Management Journal, 31(4), 854-872.

McWilliams, A., \& Siegel, D. (2001). Corporate social responsibility: A theory of the firm perspective. Academy of Management Review, 26(1), 117-127.

Mishra, S., \& Modi, S. B. (2016). Corporate social responsibility and shareholder wealth: The role of marketing capability. Journal of Marketing, 80(1), 26-46.

Mocan, M., Rus, S., Draghici, A., Ivascu, L., \& Turi, A. (2015). Impact of corporate social responsibility practices on the banking industry in Romania. Procedia Economics and Finance, 23, 712-716.

Montiel, I., Husted, B. W., \& Christmann, P. (2012). Using private management standard certification to reduce information asymmetries in corrupt environments. Strategic Management Journal, 33(9), 1103-1113. 
Morgan, R. M., \& Hunt, S. D. (1994). The commitment-trust theory of relationship marketing. Journal of Marketing, 58(3), 20-38.

Murray, K. B., \& Vogel, C. M. (1997). Using a hierarchy-of-effects approach to gauge the effectiveness of corporate social responsibility to generate goodwill toward the firm: Financial versus nonfinancial impacts. Journal of Business Research, 38(2), 141-159.

Mwiya, B. M., Wang, Y., Kaulungombe, B., \& Kayekesi, M. (2018). Exploring entrepreneurial intention's mediating role in the relationship between self-efficacy and nascent behaviour: evidence from Zambia, Africa. Journal of Small Business and Enterprise Development, 26(4), 466-485.

Noyoo, N. (2010). Linking corporate social responsibility and social policy in Zambia. In Corporate Social Responsibility and Regulatory Governance (pp. 105-123). Palgrave Macmillan, London.

Owen, C. L., \& Scherer, R. F. (1993). Social responsibility and market share. Review of Business, 15(1), 11.

Pallant, J. F., Haines, H. M., Green, P., Toohill, J., Gamble, J., Creedy, D. K., \& Fenwick, J. (2016). Assessment of the dimensionality of the Wijma delivery expectancy/experience questionnaire using factor analysis and Rasch analysis. BMC pregnancy and childbirth, 16(1), 361.

Paulík, J., Kombo, F., \& Ključnikov, A. (2015). CSR as a driver of satisfaction and loyalty in commercial banks in the Czech Republic. Journal of International Studies 8(3), 112-127.

Perez A. (2013). The effect of Corporate Associations on consumer behaviors. European Journal of Marketing 478(1/2), 218-238.

Pérez, A., \& del Bosque, I.R (2015). Corporate social responsibility and customer loyalty: exploring the role of identification, satisfaction and type of company. Journal of Services Marketing, 29(1), 1525.

Perez-Batres, L. A., Doh, J. P., Miller, V. V., \& Pisani, M. J. (2012). Stakeholder pressures as determinants of CSR strategic choice: Why do firms choose symbolic versus substantive selfregulatory codes of conduct?. Journal of Business Ethics, 110(2), 157-172.

Phiri, O., Mantzari, E., \& Gleadle, P. (2019). Stakeholder interactions and corporate social responsibility (CSR) practices: Evidence from the Zambian copper mining sector. Accounting, Auditing \& Accountability Journal, 32(1), 26-54.

Pivato, S., Misani, N., \& Tencati, A. (2008). The impact of corporate social responsibility on consumer trust: the case of organic food. Business Ethics: A European Review, 17(1), 3-12.

Poolthong, Y., \& Mandhachitara, R. (2009). Customer expectations of CSR, perceived service quality and brand effect in Thai retail banking. International Journal of Bank Marketing, 27(6), 408-427.

Preacher, K. J., \& Hayes, A. F. (2004). SPSS and SAS procedures for estimating indirect effects in simple mediation models. Behaviour research methods, instruments, \& computers, 36(4), 717-731.

Preacher, K. J., \& Hayes, A. F. (2008). Asymptotic and resampling strategies for assessing and comparing indirect effects in multiple mediator models. Behaviour Research Methods, 40(3), 879-891.

Ramchander, S., Schwebach, R. G., \& Staking, K. (2012). The informational relevance of corporate social responsibility: Evidence from DS400 index reconstitutions. Strategic Management Journal, 33, 303-314.

Rupp, D. E., Ganapathi, J., Aguilera, R. V., \& Williams, C. A. (2006). Employee reactions to corporate social responsibility: An organizational justice framework. Journal of Organizational Behavior: The International Journal of Industrial, Occupational and Organizational Psychology and Behavior, 27(4), 537-543.

Saeidi, S. P., Sofian, S., Saeidi, P., Saeidi, S. P., \& Saaeidi, S. A. (2015). How does corporate social responsibility contribute to firm financial performance? The mediating role of competitive advantage, reputation, and customer satisfaction. Journal of Business Research, 68(2), 341-350.

Saunders, M. N., \& Lewis, P. (2012). Doing research in business \& management: An essential guide to planning your project. Pearson.

Schwartz, M. S., \& Carroll, A. B. (2003). Corporate social responsibility: A three-domain 
approach. Business Ethics Quarterly, 13(4), 503-530.

Shen, C. H., Wu, M. W., Chen, T. H., \& Fang, H. (2016). To engage or not to engage in corporate social responsibility: Empirical evidence from global banking sector. Economic Modelling, 55, 207-225.

Simpasa, A., Shimeles, A., \& Salami, A. O. (2015). Employment effects of multilateral development bank support: The case of the African development bank. African Development Review, 27(S1), 31-43.

Sirdeshmukh, D., Singh, J., \& Sabol, B. (2002). Consumer trust, value, and loyalty in relational exchanges. Journal of Marketing, 66(1), 15-37.

So, K. K. F., King, C., Sparks, B. A., \& Wang, Y. (2013). The influence of customer brand identification on hotel brand evaluation and loyalty development. International Journal of Hospitality Management, 34, 31-41.

Soulsby, L. K., \& Bennett, K. M. (2015). Marriage and psychological wellbeing: the role of social support. Psychology, 6(11), 1349.

Sourvinou, A., \& Filimonau, V. (2018). Planning for an environmental management programme in a luxury hotel and its perceived impact on staff: an exploratory case study. Journal of Sustainable Tourism, 26(4), 649-667.

Spence, A.M. (1974). Market Signaling: Informational Transfer in Hiring and Related Screening Processes, Harvard University Press, Cambridge, MA.

Spence, M. (1973). Market Signalling: Information Transfer in Hiring and Related Processes. Cambridge, MA.

Stanwick, P. A., \& Stanwick, S. D. (1998). The relationship between corporate social performance, and organizational size, financial performance, and environmental performance: An empirical examination. Journal of Business Ethics, 17(2), 195-204.

Story, J., \& Neves, P. (2015). When corporate social responsibility (CSR) increases performance: exploring the role of intrinsic and extrinsic CSR attribution. Business Ethics: A European Review, 24(2), 111-124.

Su, W., Peng, M. W., Tan, W., \& Cheung, Y. L. (2016). The signaling effect of corporate social responsibility in emerging economies. Journal of Business Ethics, 134(3), 479-491.

Swaen, V., \& Chumpitaz, R. C. (2008). Impact of corporate social responsibility on consumer trust. Recherche et Applications en Marketing (English Edition), 23(4), 7-34.

Swickert, R. J., Hittner, J. B., \& Foster, A. (2012). A proposed mediated path between gender and posttraumatic growth: the roles of empathy and social support in a mixed-age sample. Psychology, 3(12), 1142.

Teoh, S. H., Welch, I., \& Wazzan, C. P. (1999). The effect of socially activist investment policies on the financial markets: Evidence from the South African boycott. The Journal of Business, 72(1), 3589.

Thompson, E. R. (2009). Individual entrepreneurial intent: Construct clarification and development of an internationally reliable metric. Entrepreneurship Theory and Practice, 33(3), 669-694.

Turban, D. B., \& Greening, D. W. (1996). Corporate social performance and organizational attractiveness to prospective employees. Academy of Management Journal, 40(3), 658-672.

Van Knippenberg, D., \& Sleebos, E. (2006). Organizational identification versus organizational commitment: self-definition, social exchange, and job attitudes. Journal of Organizational Behavior: The International Journal of Industrial, Occupational and Organizational Psychology and Behavior, 27(5), 571-584.

Visser, W. (2006). Revisiting Carroll's CSR pyramid. Corporate citizenship in developing countries, 2956.

Vlachos, P. A., Tsamakos, A., Vrechopoulos, A. P., \& Avramidis, P. K. (2009). Corporate social responsibility: attributions, loyalty, and the mediating role of trust. Journal of the Academy of Marketing Science, 37(2), 170-180.

Walsh, G., \& Bartikowski, B. (2013). Exploring corporate ability and social responsibility associations as antecedents of customer satisfaction cross-culturally. Journal of Business Research, 66(8), 989- 

995.

Wright, P., \& Ferris, S. P. (1997). Agency conflict and corporate strategy: The effect of divestment on corporate value. Strategic Management Journal, 18(1), 77-83.

Wu, M. W., \& Shen, C. H. (2013). Corporate social responsibility in the banking industry: Motives and financial performance. Journal of Banking \& Finance, 37(9), 3529-3547.

Xu, D., \& Meyer, K. E. (2013). Linking theory and context:'Strategy research in emerging economies' after Wright et al.(2005). Journal of Management Studies, 50(7), 1322-1346.

Yadav R.S, Dash S.S , Chakraborty S. and Kumar M. (2018). Perceived CSR and Corporate Reputation: The Mediating Role of Employee Trust. The Journal of Decision Markers 43(3), 139-151.

Yadav, S. K., Agrawa, V., Khandelwal, U., \& Tripathi, V. (2018). Customer Satisfaction and Loyalty Relationship: The Mediating Role of Trust. IUP Journal of Marketing Management, 17(2).

Zambia Daily Mail, (2018). Banks can give more to communities, Available for < http://www.dailymail.co.zm/banks-can-give-more-to-communities/> [accessed on 23/01/2019].

Zanaco Report (2018). Corporate Social Responsibility (available from https://www.zanaco.co.zm/zanaco-csr.php [accessed on 14/03/2019]

Zeithaml, V. A., Berry, L. L., \& Parasuraman, A. (1996). The behavioral consequences of service quality. Journal of Marketing, 60(2), 31-46.

Zhao, X., Lynch Jr, J. G., \& Chen, Q. (2010). Reconsidering Baron and Kenny: Myths and truths about mediation analysis. Journal of Consumer Research, 37(2), 197-206.

Ziek, P. (2009). Making sense of CSR communication. Corporate Social Responsibility and

Environmental Management, 16(3), 137-145s 